\title{
Citrate-Zn/Al Layered Double Hydroxide as Adsorbent of Congo Red from Aqueous Solution
}

\author{
Nurlisa Hidayati ${ }^{1}$, Neza Rahayu Palapa ${ }^{1}$, Bakri Rio Rahayu ${ }^{1}$, Risfidian Mohadi ${ }^{1,2}$, Elfita ${ }^{1}$ \\ and Aldes Lesbani ${ }^{1,2,3, *}$ \\ ${ }^{1}$ Department of Chemistry, Faculty of Mathematics and Natural Sciences, Universitas Sriwijaya, Jl. Palembang \\ Prabumulih Km.32 Ogan Ilir 30662, Indonesia \\ ${ }^{2}$ Research Center of Inorganic Materials and Coordination Complexes, Faculty of Mathematics and Natural \\ Sciences, Universitas Sriwijaya, J1. Palembang Prabumulih Km.32 Ogan Ilir 30662, Indonesia \\ ${ }^{3}$ Graduate School of Mathematics and Natural Sciences, Faculty of Mathematics and Natural Sciences, \\ Universitas Sriwijaya, Jl. Palembang Prabumulih Km.32 Ogan Ilir 30662, Indonesia
}

\begin{abstract}
Layered double hydroxide ( $\mathrm{LDH}$ ) of $\mathrm{Zn} / \mathrm{Al}$ and citrate- $\mathrm{Zn} / \mathrm{Al}$ was prepared and used as an adsorbent of Congo red from aqueous solution. LDH was characterized by X-ray, FTIR, and BET analysis. Adsorption of Congo red was studied through kinetic, isotherm, and thermodynamic analyses. Zn/Al LDH has diffraction at $10.29^{\circ}$ (003) with interlayer distance $8.59 \AA$ and citrate-Zn/Al LDHs have anomalous diffraction at $7.57^{\circ}(003)$ with interlayer distance $11.68 \AA$. The surface area of citrate- $\mathrm{Zn} / \mathrm{Al}\left(40.50 \mathrm{~m}^{2} \mathrm{~g}^{-1}\right)$ has higher than pristine LDH $\left(1.97 \mathrm{~m}^{2} \mathrm{~g}^{-1}\right)$. Adsorption of Congo red was conducted at $\mathrm{pH} 6$ for $\mathrm{Zn} / \mathrm{Al} \mathrm{LDH}$ and at $\mathrm{pH} 8$ for citrate-Zn/Al LDH. Adsorption of Congo red on both LDHs follows the pseudo-second-order kinetic model. The isotherm parameter follows the Freundlich isotherm model with maximum adsorption capacity $166.67 \mathrm{mg} \mathrm{g}^{-1}$ for $\mathrm{Zn} / \mathrm{Al}$ and 249.99 $\mathrm{mg} \mathrm{g}^{-1}$ for citrate-Zn/Al LDH. Adsorption of Congo red on both LDHs was classified as physical adsorption with energy 4.085-4.148 kJ mol-1.
\end{abstract}

Keywords: citric acid, layered double hydroxide, $\mathrm{Zn} / \mathrm{Al}$, adsorption, Congo red.

\section{Introduction}

The use of dyes in the industrial process such as painting, film, textile, plastic, pigment, and so on is sharply increased. It causes an environmental problem due to the undegradable properties of dyes. Various methods have been applied to remove stains from an aqueous solution such as adsorption ${ }^{1,2}$, precipitation ${ }^{3}$, filtration ${ }^{4}$, coagulation ${ }^{5}$, membrane ${ }^{6}, \ldots$ Among these methods, adsorption is a suitable method to remove dyes due to the easy way, simple process, and also low-cost process ${ }^{7,8}$. The efficiency of the adsorption process depends on the properties of adsorbent.

Wide range organic and inorganic adsorbent has been used to reduce dyes from an aqueous solution such as chitin, chitosan ${ }^{9}$, cellulose ${ }^{10}$, bentonite ${ }^{11}$, kaolin ${ }^{12}$, clay $^{13}$, carbon nanotube ${ }^{14}$, zeolite ${ }^{15}$, and also layered double hydroxide $(\mathrm{LDH})^{16-18}$. $\mathrm{LDH}$ is inorganic layer material with the general formula $\left[\mathrm{M}^{2+} / \mathrm{M}^{3+}(\mathrm{OH})\right.$ ]$_{\mathrm{x}}{ }^{+}\left[\mathrm{A}^{\mathrm{n}-}\right] \cdot \mathrm{mH}_{2} \mathrm{O}$ where $\mathrm{M}^{2+/} \mathrm{M}^{3+}$ is divalent and trivalent metal ions, from stacking brucite-like layers metal oxide containing a positive charge due to partial substitution of divalent metal cation by trivalent metal cation ${ }^{19}$. The negative charge is represented by *Corresponding author: Aldes Lesbani

Email address: aldeslesbani@pps.unsri.ac.id DOI: http://dx.doi.org/10.13171/mjc02003131281al anions located in the interlamellar spaces. Interlamellar space is also known as interlayer, can exchange species $\mathrm{A}^{\mathrm{n}-}$ to other anions ${ }^{20}$. The interlayer can be expanded to an adapted wide range of interlayer anion. Therefore, $\mathrm{A}^{\mathrm{n}-}$ can be exchangeable with inorganic or organic anionic compounds, such as polyoxometalate ${ }^{21-22}$, halide ${ }^{23}$, nitrate, phosphate, carbonate ${ }^{24}$, and also EDTA ${ }^{25}$.

The LDH showed the efficient material as adsorbent of anionic and cationic of dyes such as Congo red ${ }^{26}$, safranin ${ }^{27}$, indigo carmin ${ }^{28}$, crystal violet and malachite green ${ }^{29}$, and also methylene blue ${ }^{30}$. $\mathrm{LDH}$ $\left.\mathrm{M}^{2+} / \mathrm{M}^{3+}\left(\mathrm{M}^{2+}=\mathrm{Zn}\right), \mathrm{M}^{3+}=\mathrm{Al}, \mathrm{Fe}, \mathrm{Cr}\right)$ were used as adsorbent of direct violet follow pseudo-second-order kinetic adsorption model rather than pseudo-firstorder model ${ }^{31}$. $\mathrm{Zn} / \mathrm{Cr} \mathrm{LDH}$ was also used as an efficient adsorbent of Congo red and direct yellow dyes, which were an anionic dyes ${ }^{32}$. Based on these results, the use of $\mathrm{LDH}$ as an efficient adsorbent of dyes is the priority. On the other hand, modification of LDH by intercalation with anion onto interlayer distance has been conducted to increase interlayer distance and surface area properties of $\mathrm{LDH}$. $\mathrm{Zn} / \mathrm{Cr}$ $\mathrm{LDH}$ has been intercalated with $\left[\alpha-\mathrm{SiW}_{12} \mathrm{O}_{40}\right]^{4-}$ to

Received December 23, 2019

Accepted January 2, 2020

Published December 13, 2020 
form $\mathrm{Zn} / \mathrm{Cr}-\left[\alpha-\mathrm{SiW}_{12} \mathrm{O}_{40}\right]$ by substitution of Keggin type polyoxometalate to nitrate ion of $\mathrm{Zn} / \mathrm{Cr} \mathrm{LDH}$ resulted increasing the surface area from $31.638 \mathrm{~m}^{2} / \mathrm{g}$ to $128.871 \mathrm{~m}^{2} / \mathrm{g}$ after intercalation process ${ }^{33}$. This material after intercalation was effective as inorganic adsorbent. Organic anions such as citrate and malate have been applied as intercalant of $\mathrm{Mg} / \mathrm{Al} \mathrm{LDH}$ and show efficient as an adsorbent for removal lead and copper ${ }^{34}$.
In this research, $\mathrm{Zn} / \mathrm{Al} \mathrm{LDH}$ was intercalated with citrate ion to increase both interlayer distance and surface area properties of LDH. The material was used as an adsorbent for Congo red from water. The effect of various conditions, including $\mathrm{pH}$, time, initial concentration, and temperature adsorption were investigated in batch adsorption apparatus. Kinetic, isotherm, and thermodynamic adsorption of Congo red on citrate- $\mathrm{Zn} / \mathrm{Al} \mathrm{LDH}$ was discussed in this article. The structure of Congo red was shown in Figure 1.



Figure 1. Structure of Congo Red

\section{Experimental Section}

\subsection{Chemicals and Instrumentations}

Chemicals were supplied from Merck and Sigma Aldrich, such as zinc nitrate, aluminum nitrate, sodium hydroxide, hydrochloric acid, sodium carbonate, citric acid, and Congo red. These reagents were used directly after purchased without further purification. Water was obtained from the water purification Purite ${ }^{\circledR}$ water purification system equipped with an ion-exchange system at Universitas Sriwijaya. X-ray analysis was conducted using XRD powder Rigaku Miniflex-6000. The sample was homogenized using a mortar and scanned at scan speed $1^{\circ} \mathrm{min}^{-1}$. FTIR spectra were recorded using Shimadzu FTIR Prestige- 21 by $\mathrm{KBr}$ method. The sample was examined at wavenumber $400-4000 \mathrm{~cm}^{-}$ 1. Surface area analysis was measured using a Quantachrome instrument at 77K. Congo red dye was analyzed using spectrophotometer UV-Vis BioBase BK-UV $1800 \mathrm{PC}$ at wavelength $497 \mathrm{~nm}$.

\subsection{Preparation of $\mathrm{Zn} / \mathrm{Al}$ and Intercalated Citric Acid Zn/Al Layered Double Hydroxides}

$\mathrm{Zn} / \mathrm{Al} \mathrm{LDH}$ was synthesized using the coprecipitation method at $\mathrm{pH} 10^{35}$. The solution of zinc nitrate $(0.3$ $\mathrm{M}, 100 \mathrm{~mL})$ and aluminum nitrate $(0.1 \mathrm{M}, 100 \mathrm{~mL})$ was mixed under constant stirring. The mixture of sodium hydroxide (1 M, $50 \mathrm{~mL}$ ) and sodium carbonate $(1 \mathrm{M}, 50 \mathrm{~mL})$ was added into the mixture, and the $\mathrm{pH}$ of the solution mixture was adjusted to 10 by adding sodium hydroxide. The reaction was performed overnight to form a white solid material. The solid material was washed with water and dried at $110^{\circ} \mathrm{C}$ for 24 hours.

Citric acid-Zn/Al LDH was prepared using the gel method under nitrogen conditions. A citric acid solution (4 g in $250 \mathrm{~mL}$ water) was added to a gel form of $\mathrm{Zn} / \mathrm{Al} \mathrm{LDH}$. The reaction mixture was stirred at $60^{\circ} \mathrm{C}$ for 1 hour, $\mathrm{pH}$ was adjusted to 10 by adding sodium hydroxide solution then the reaction was kept with constant stirring for 24 hours to form citrate$\mathrm{Zn} / \mathrm{Al} \mathrm{LDH}$.

\section{3. pH pzc determination ${ }^{36}$}

The $\mathrm{pH}$ at the point zero charge of materials was conducted using $0.05 \mathrm{~g}$ adsorbents added into $50 \mathrm{~mL}$ the solution of sodium chloride $0.1 \mathrm{M}$ under various $\mathrm{pH}$ conditions using hydrochloride acid or sodium hydroxide solution. The solution of sodium chloride $0.1 \mathrm{M}$ was adjusted to $\mathrm{pH}$ in the range $1-10$ by addition hydrochloric acid $0.1 \mathrm{M}$ of sodium hydroxide $0.1 \mathrm{M}$ solutions. The material of $\mathrm{Zn} / \mathrm{Al}$ and citric acid-Zn/Al LDH was added into the series of $\mathrm{pH}$ solution, and then the solution mixtures were stirred continuously for 24 hours. The solutions were filtered, and $\mathrm{pH}$ of the filtrate was determined by $\mathrm{pH}$ meter. The graph of $\mathrm{pH}$ pzc was obtained by comparison initial and final $\mathrm{pH}$ solution.

\subsection{Study Mixture adsorption}

Adsorption of dye using $\mathrm{Zn} / \mathrm{Al}$ and citrate- $\mathrm{Zn} / \mathrm{Al}$ LDHs was firstly investigated through mixtures dyes adsorption. Congo red, methyl orange and malachite green were mixed to determine the adsorption competition of dyes. The dyes mixtures were conducted at the acid and base condition. Congo red and methyl orange were anionic dyes, whereas malachite green was cationic dye. The time of adsorption was varied from 5 to 120 minutes. The filtrate was scanned using UV-Vis spectrophotometer in the range $400-700 \mathrm{~nm}$. 


\subsection{Adsorption of Congo Red}

Adsorption of Congo red with $\mathrm{Zn} / \mathrm{Al}$ and citrate$\mathrm{Zn} / \mathrm{Al}$ LDHs was carried out using a batch small reactor system. Adsorption was studied through the effect of adsorption time, the effect of Congo red concentration, and adsorption temperature. Effect of adsorption time was investigated at various adsorption time i.e. 5, 10, 15, 20, 30, 50, 70, 90, 120,
150, 180 minutes. The effect of Congo red concentration was varied at 40,50,60,80 $\mathrm{mg} \mathrm{L}^{-1}$ and at temperature $303,313,323,333 \mathrm{~K}$. Concentration of Congo red after adsorption process was analyzed using UV-vis spectrophotometer at $497 \mathrm{~nm}$.

\section{Results and Discussion}

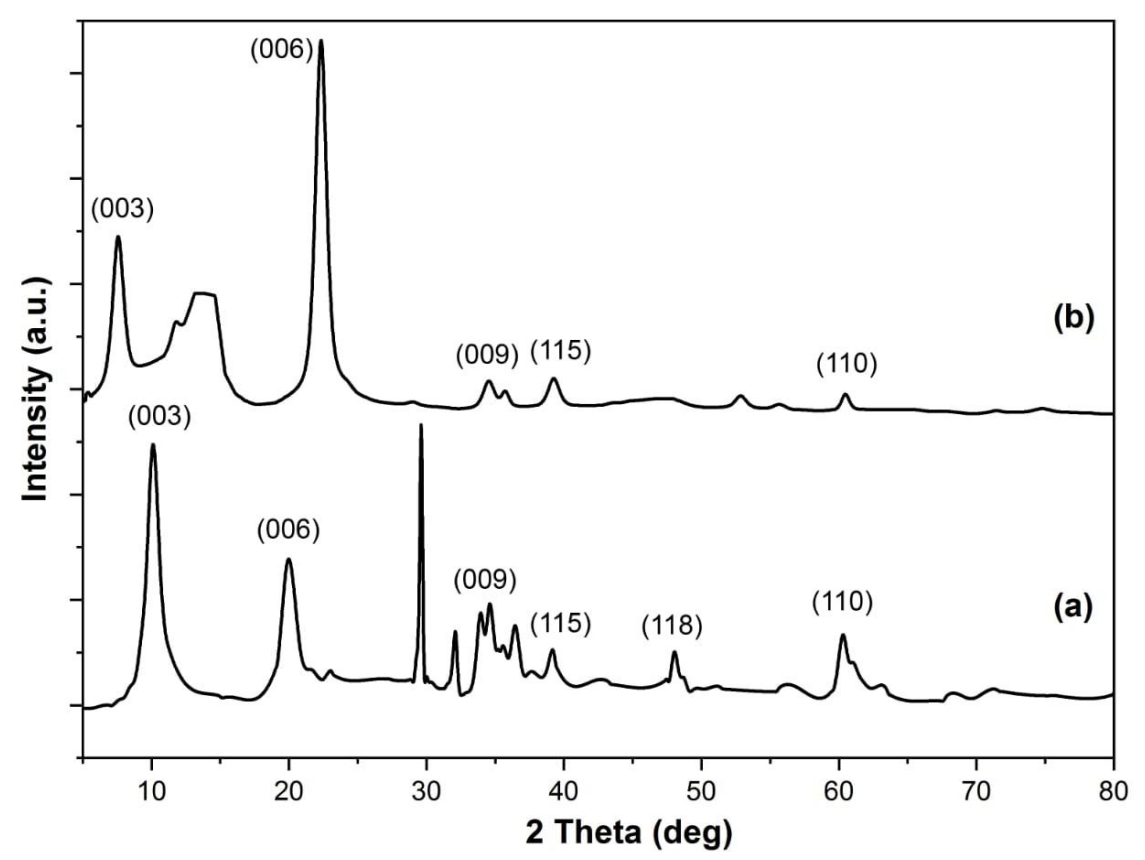

Figure 2. XRD powder patterns of $\mathrm{Zn} / \mathrm{Al}$ (a) and citrate-Zn/Al (b) LDHs

The XRD powder patterns of $\mathrm{Zn} / \mathrm{Al}$ and citrate $-\mathrm{Zn} / \mathrm{Al}$ LDHs are shown in Figure 2. Zn/Al LDH has diffraction peak at $10.29^{\circ}(003), 20.07^{\circ}(006)$, $31.50^{\circ}(009), \quad 39.60 \quad(115), \quad 48.95^{\circ}(118)$, and $60.20^{\circ}(110){ }^{37}$. The diffraction peak at $31.50^{\circ}$ indicates the formation of carbonate on the interlayer distance of $\mathrm{Zn} / \mathrm{Al} \mathrm{LDH}$. The formation of a wellordered layer structure was identified at $10.29^{\circ}$ and $60.20^{\circ}$ with an interlayer distance of $8.59 \AA$ at diffraction 10.29 (003). The intercalation of $\mathrm{Zn} / \mathrm{Al}$ LDH with citric acid has slightly changed the diffraction peaks. The crystallinity of material after the intercalation process was decreased, as indicated by the formation of a diffraction peak at $15^{\circ}$. The diffraction of (003) was shifted to $7.56^{\circ}$ with interlayer distance $11.68 \AA$. Other peaks was detected at $\quad 24.35^{\circ}(006), \quad 34.50^{\circ}(009), \quad 39.89^{\circ}(115)$, $60.42^{\circ}(110)$. The interlayer distance of $\mathrm{Zn} / \mathrm{Al} \mathrm{LDH}$ was expanded because of the insertion of citrate ion. The citric acid size is approximately $7.2 \AA$ thus citrate ion was inserted as slanted orientation as illustrated in Figure 3.

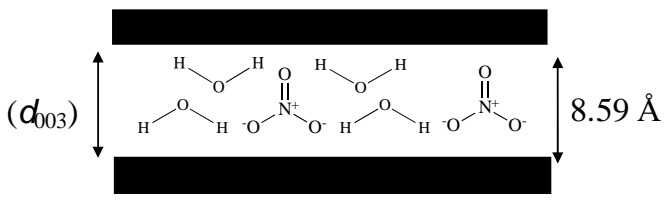

$\mathrm{Zn} / \mathrm{Al} \mathrm{LDH}$

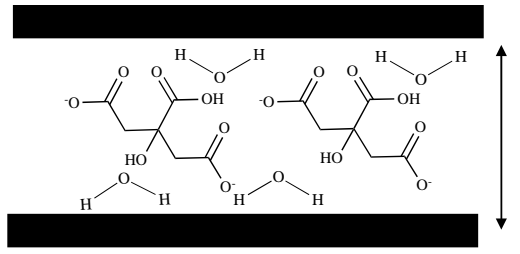

Intercalated $\mathrm{Zn} / \mathrm{Al} \mathrm{LDH}$

Figure 3. Structure of LDH and intercalated with citrate ion. 


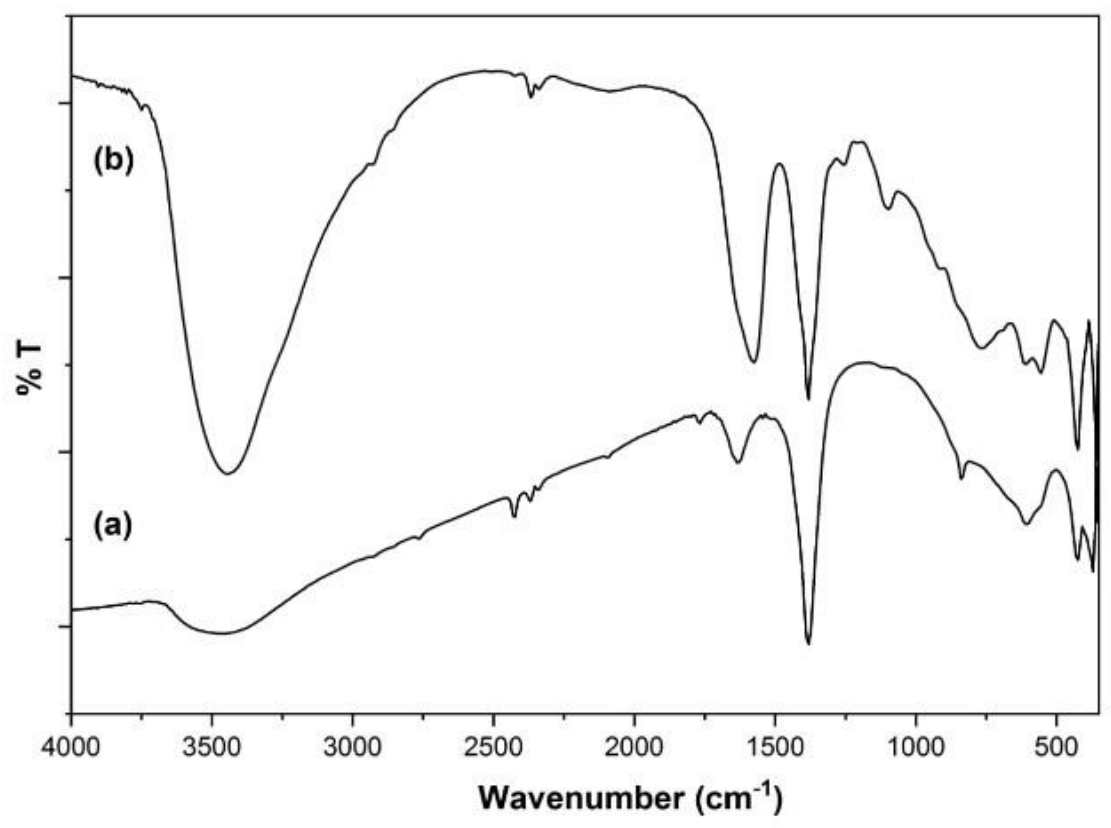

Figure 4. FTIR spectra of $\mathrm{Zn} / \mathrm{Al}$ (a) and citrate $-\mathrm{Zn} / \mathrm{Al}$ (b) LDHs

The FTIR spectra of $\mathrm{Zn} / \mathrm{Al}$ and intercalated $\mathrm{Zn} / \mathrm{Al}$ LDHs with citric acid are shown in Figure 4. As shown in Figure $4 \mathrm{a}$, the board peak at $3400 \mathrm{~cm}^{-1}$ was assigned as the $-\mathrm{O}-\mathrm{H}$ stretching vibration. These vibrations are coming from the water on interlayer distance, water on the hydroxide layer, and also adsorbed water from the air. Water also has to bend vibration at $1610 \mathrm{~cm}^{-1}$ as small vibration in Figure 4a. The sharp peak vibration at $1370 \mathrm{~cm}^{-1}$ is attributed to carbonate vibration. Intercalation of $\mathrm{Zn} / \mathrm{Al}$ with citrate ion resulted in sharp vibration of citrate ion at $1600 \mathrm{~cm}^{-1}$ as vibration $\mathrm{C}=\mathrm{O}$. The vibration of carbonate has still remained. The $-\mathrm{CH}_{2}$ - the vibration of citrate ion was detected at $2900 \mathrm{~cm}^{-1}$ with a small vibration peak. The vibration of water molecule appeared extremely board at $3400 \mathrm{~cm}^{-1}$, similar to pristine $\mathrm{LDH}^{38}$.

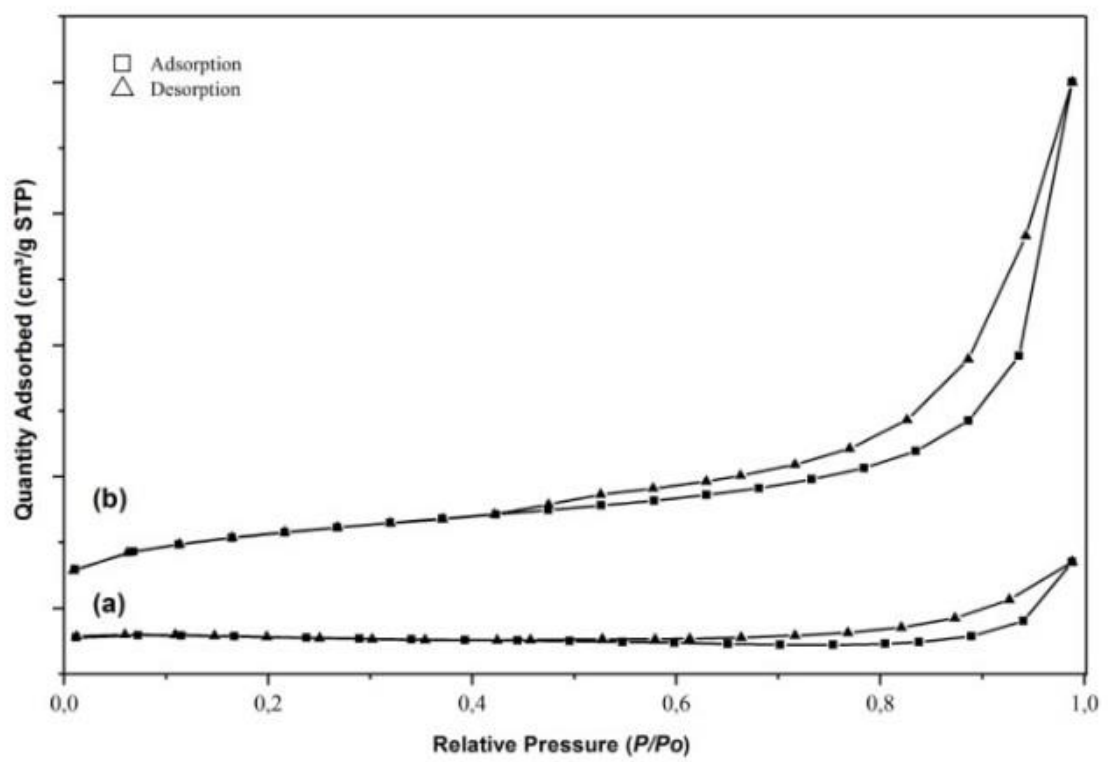

Figure 5. Nitrogen adsorption-desorption profile of $\mathrm{Zn} / \mathrm{Al}$ (a) and citric acid-Zn/Al (b) LDHs

The surface area of $\mathrm{Zn} / \mathrm{Al} \mathrm{LDH}$ and intercalated $\mathrm{Zn} / \mathrm{Al}$-citrate LDH were determined by nitrogen adsorption-desorption. The adsorption-desorption isotherm of materials is shown in Figure 5. There is a hysteresis loop with $\mathrm{H} 3$ type on both $\mathrm{Zn} / \mathrm{Al}$ and intercalated materials ${ }^{39}$. The materials are classifying as mesoporous. The BET analysis is shown in Table 1 and shows that pore diameter was slightly decreased 
after intercalation, but the significant increase of surface area and pore volume after intercalation with citric acid. The morphologies of $\mathrm{Zn} / \mathrm{Al}$ and $\mathrm{Zn} / \mathrm{Al}$ citrate LDH were represented in Figure 6.
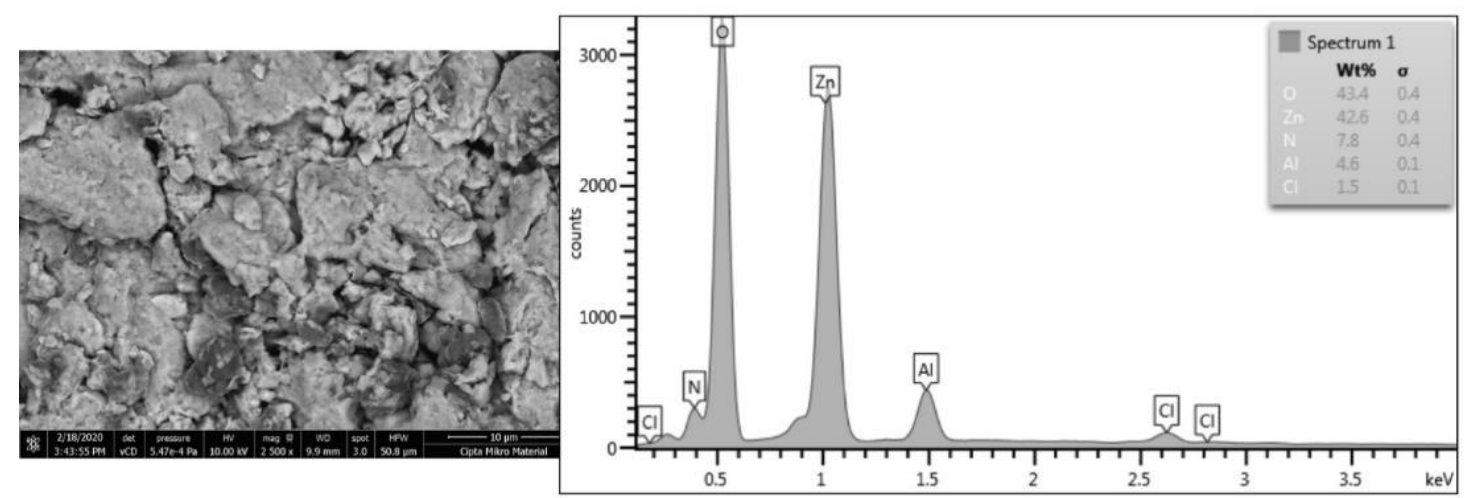

(a)
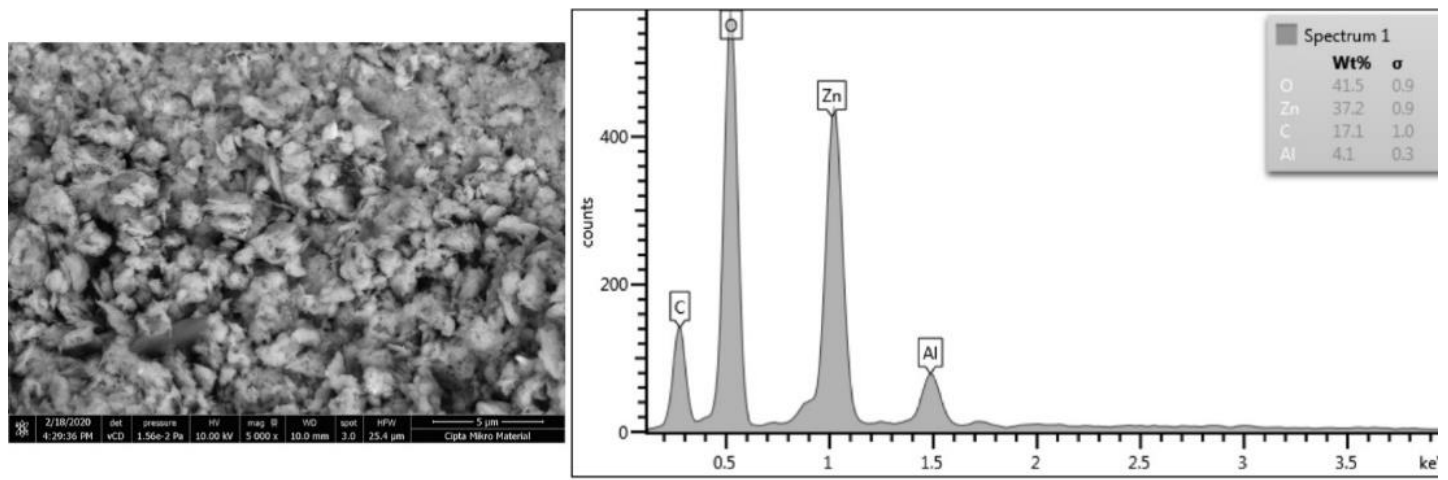

(b)

Figure 6. SEM images and composition of Zn/Al LDH (a) and Zn/Al-citrate (b)

Figure 6.a shows the morphology of $\mathrm{Zn} / \mathrm{Al}$ before citrate intercalation. The morphology of $\mathrm{Zn} / \mathrm{Al}$ shows the agglomeration of materials caused the $\mathrm{pH}$ setting and temperature due to the synthesis process. Similar reported by Palapa et al (2020), that the agglomeration of LDH indicated the heterogeneity in surface area and active site become low ${ }^{40}$. According to EDX composition Figure 6.a. shows the dominant component is oxygen from water and anion; $\mathrm{Zn}$ forms divalent metal of $\mathrm{LDH} ; \mathrm{N}$ from nitrate and also $\mathrm{Al}$ from trivalent metal cation of LDH structure. Figure 6.b indicated the intercalation process was successfully conducted and EDX composition of the material was presented. The morphology of $\mathrm{Zn} / \mathrm{Al}-$ citrate also shows the agglomeration of materials. The white particle indicated the morphology of citrate. According to Rahmanian et al. (2018), the LDH intercalated citrate anion has homogeneity plates-like shape with nano-size particles ${ }^{41}$.

Table 1. BET Analysis.

\begin{tabular}{|c|c|c|}
\hline \multirow{2}{*}{ Properties } & \multicolumn{2}{|c|}{ LDHs } \\
\cline { 2 - 3 } & $\mathrm{Zn} / \mathrm{Al}$ & Citrate-Zn/Al \\
\hline BET surface $a r e a\left(\mathrm{~m}^{2} \mathrm{~g}^{-1}\right)$ & 1.968 & 40.502 \\
\hline Pore volume $\left(\mathrm{cm}^{3} \mathrm{~g}^{-1}\right), \mathrm{BJH}$ & 0.006 & 0.116 \\
\hline Pore diameter $(\mathrm{nm}), \mathrm{BJH}$ & 27.687 & 16.350 \\
\hline
\end{tabular}

The surface charges of material were determined using $\mathrm{pH}$ pzc (point zero charges), as shown in Figure 7. The intersection point of $\mathrm{Zn} / \mathrm{Al} \mathrm{LDH}$ was at $\mathrm{pH} 6$, whereas intercalated material at $\mathrm{pH} 8$. At that point, the surface charges of materials were zero. The point of under $\mathrm{pH}$ pzc indicated that the materials' surface is positively charge and vice versa. Thus the application of adsorption was conducted at $\mathrm{pH}$ pzc. 


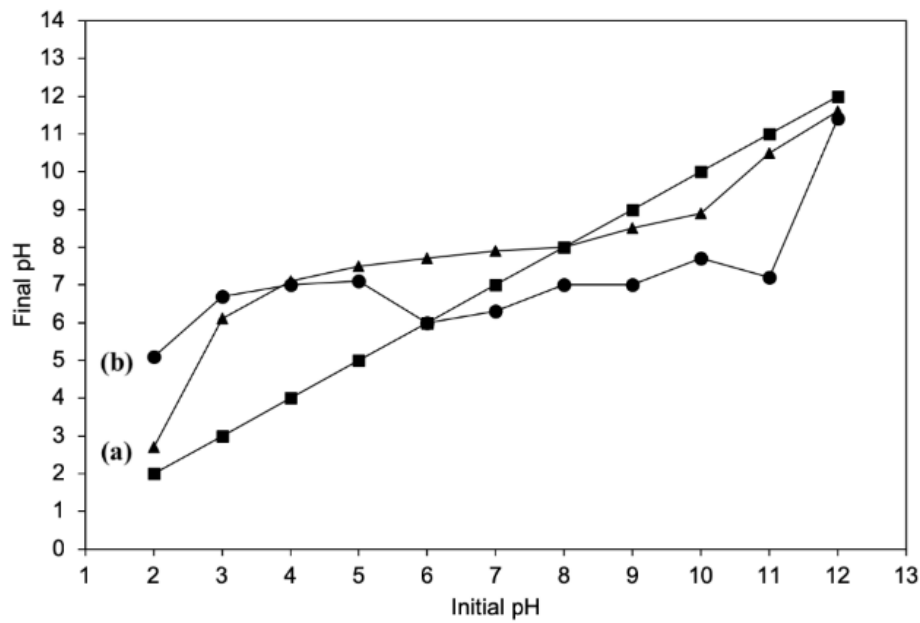

Figure 7. $\mathrm{pH}$ pzc graph of initial $\mathrm{pH}(\mathrm{a}), \mathrm{Zn} / \mathrm{Al}$ (b) and citrate-Zn/Al
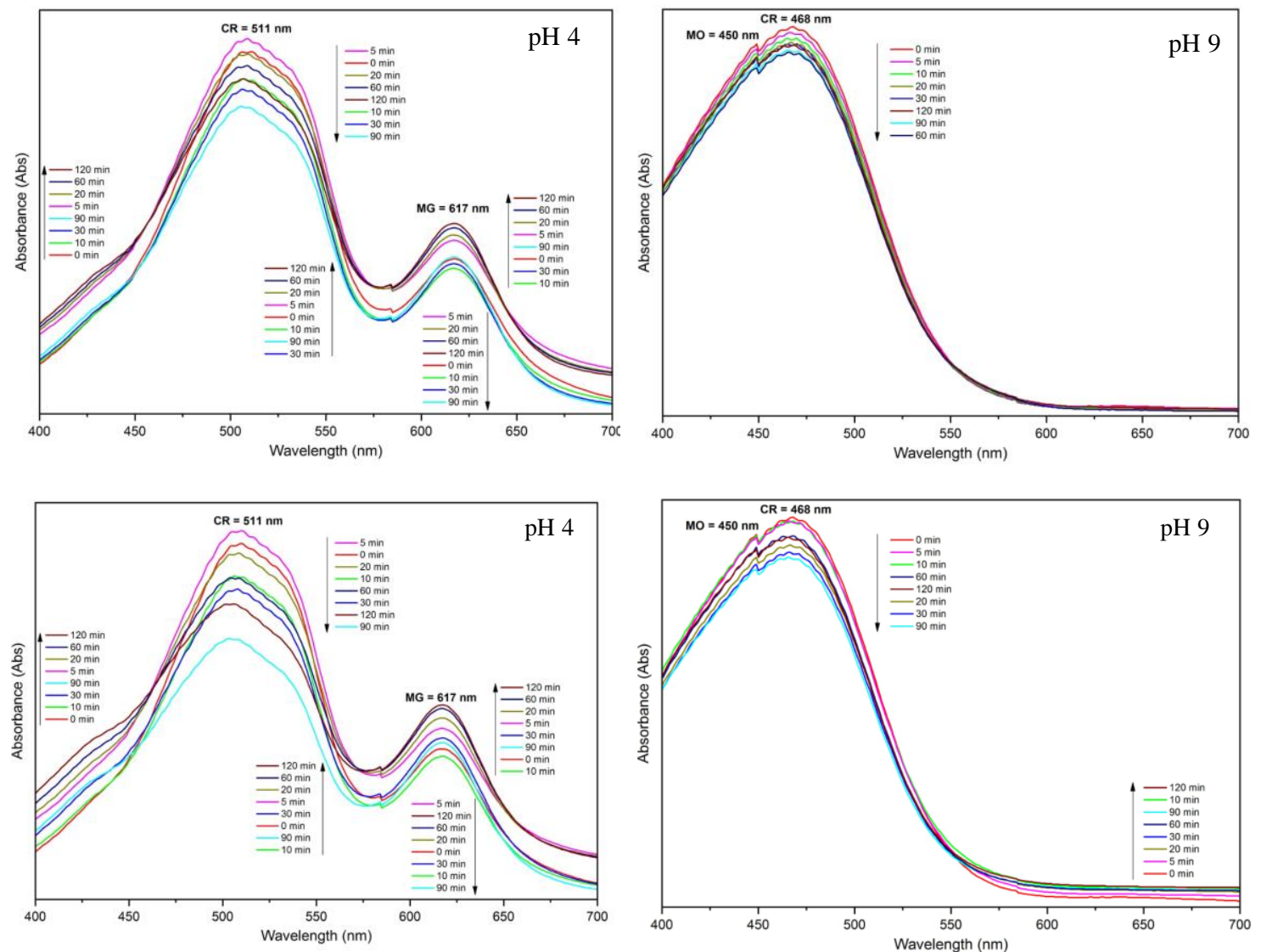

Figure 8. UV-visible spectra of a mixture of dyes (congo red, methyl orange, malachite green) with pH 4 (above) and $\mathrm{pH} 9$ (below) after treating with $\mathrm{Zn} / \mathrm{Al}$ and citric acid-Zn/Al LDHs

Figure 8 shows the adsorption of mixture dyes using $\mathrm{Zn} / \mathrm{Al}$ and citrate-Zn/Al LDHs. The dyes were Congo red and methyl orange as anionic dyes and malachite green as a cationic dye. The adsorption was conducted at $\mathrm{pH}$ acid and base. All dyes were detected at acid condition, but malachite green was not detected at base condition due to anionic dyes reacted with a hydroxyl group. At acid condition, the absorbance of Congo red was slightly decreased by increasing adsorption time.
On the other hand, the absorbance of methyl orange and malachite green was almost stable. The amount of Congo red was adsorbed dominantly than methyl orange or malachite green on both $\mathrm{Zn} / \mathrm{Al}$ and intercalated materials. Thus adsorption of Congo red was further investigated through the effect of adsorption time, the concentration of Congo red, and temperature adsorption. 


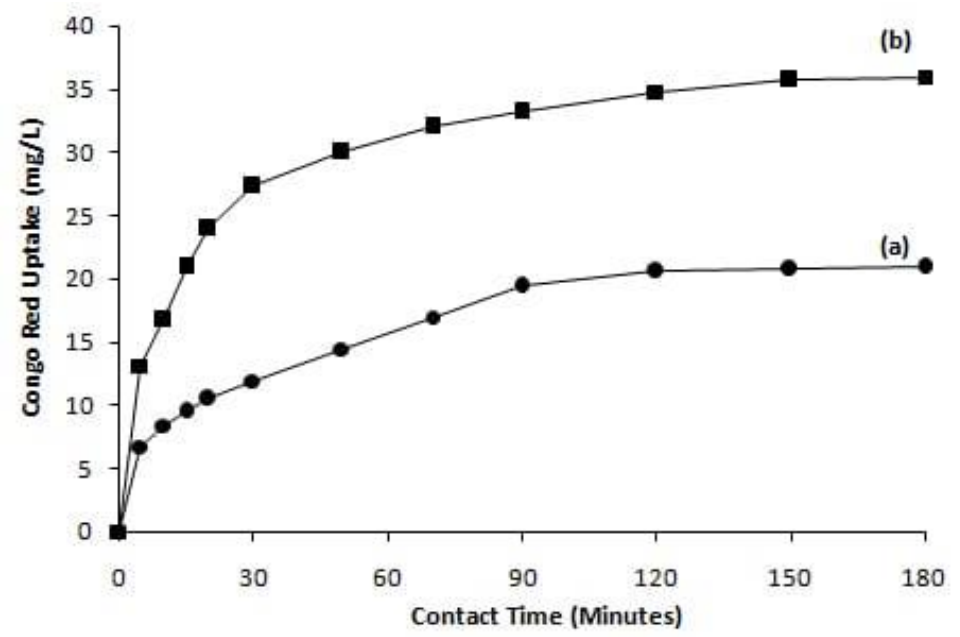

Figure 9. Effect of adsorption time on $\mathrm{Zn} / \mathrm{Al}$ (a) and citrate- $\mathrm{Zn} / \mathrm{Al}$ (b) LDHs

The effect of adsorption time of Congo red on $\mathrm{Zn} / \mathrm{Al}$ and intercalated $\mathrm{Zn} / \mathrm{Al} \mathrm{LDHs}$ material was shown in Figure 9. The adsorbed Congo red was gradually increased by increasing adsorption time and reach equilibrium at 120 minutes. Adsorption of Congo red on intercalated LDH material is higher than pristine $\mathrm{Zn} / \mathrm{Al} \mathrm{LDH}$. The data in Figure 8 was used to obtain adsorption rate $k_{1}$ and $k_{2}$ using pseudo-first-order and pseudo-second-order kinetic model as follows ${ }^{42}$ :

Pseudo first-order kinetic model:

$\log \left(\mathrm{q}_{\mathrm{e}}-\mathrm{q}_{\mathrm{t}}\right)=\log \mathrm{q}_{\mathrm{e}}-\left(\frac{k_{1}}{2,303}\right) t$ where: $\mathrm{q}_{\mathrm{e}}$ is adsorption capacity at equlibrium (mg.g$\left.{ }^{1}\right) ; \mathrm{q}_{\mathrm{t}}$ is adsorption capacity at $\mathrm{t}\left(\mathrm{mg} \cdot \mathrm{g}^{-1}\right)$; $\mathrm{t}$ is adsorption time (minute); and $k_{1}$ is adsorption kinetic rate at pseudo first-order $\left(\right.$ minute $\left.^{-1}\right)$.

Pseudo-second-order kinetic model:

$\frac{t}{q t}=\frac{1}{k 2 q e^{2}}+\frac{1}{q e} t$

where $\mathrm{q}_{\mathrm{e}}$ is adsorption capacity at equilibrium (mg. $\mathrm{g}^{-}$ $\left.{ }^{1}\right) ; \mathrm{q}_{\mathrm{t}}$ is adsorption capacity at $\mathrm{t}\left(\mathrm{mg} \cdot \mathrm{g}^{-1}\right)$; $\mathrm{t}$ is adsorption time (minute); and $k_{2}$ is adsorption kinetic rate at pseudo second-order $\left(\mathrm{g} \cdot \mathrm{mg}^{-1} \cdot\right.$ minute $\left.^{-1}\right)$. The data of kinetic adsorption is shown in Table 2.

Table 2. Kinetic model of congo red adsorption on LDH.

\begin{tabular}{|c|c|c|c|}
\hline \multirow{2}{*}{$\begin{array}{c}\text { Kinetic Adsorption } \\
\text { Model }\end{array}$} & Kinetic Parameter & \multicolumn{2}{|c|}{ LDH } \\
\cline { 2 - 3 } & & $\mathrm{Zn} / \mathrm{Al}$ & Citrate-Zn/Al \\
\hline & Qe $\left(\mathrm{mg} \mathrm{g}^{-1}\right)$ & 25.704 & 33.037 \\
Pseudo First-Order & Qe experiment $\left(\mathrm{mg} \mathrm{g}^{-1}\right)$ & 29.208 & 44.958 \\
& $\mathrm{R}^{2}$ & 0.972 & 0.971 \\
\hline & $k_{1}\left(\mathrm{~min}^{-1}\right)$ & 0.0299 & 0.0276 \\
\hline & Qe $\left(\mathrm{mg} \mathrm{g}^{-1}\right)$ & 30.303 & 50.001 \\
Pseudo Second-Order & Qe experiment $\left(\mathrm{mg} \mathrm{g}^{-1}\right)$ & 29.208 & 44.958 \\
& $\mathrm{R}^{2}$ & 0.991 & 0.999 \\
& $k_{2}\left(\mathrm{~g} \mathrm{mg}^{-1} \mathrm{~min}^{-1}\right)$ & 0.0014 & 0.0016 \\
\hline
\end{tabular}

The pseudo second-order kinetic model is appropriate for both adsorbents due to $\mathrm{R}$ value close to one. The $k_{2}$ value for intercalated material is slightly larger than $\mathrm{Zn} / \mathrm{Al}$ without intercalation. The reactivity of intercalated material is probably due to the opening of interlayer distance after intercalation. According to
Sepehr et al (2012), the kinetic models determined by coefficient correlation and the value of qe experiment are close to qe calculation ${ }^{43}$. In Table 2 . the qe experiment use pseudo-second order, both LDH close with qe calculation. 

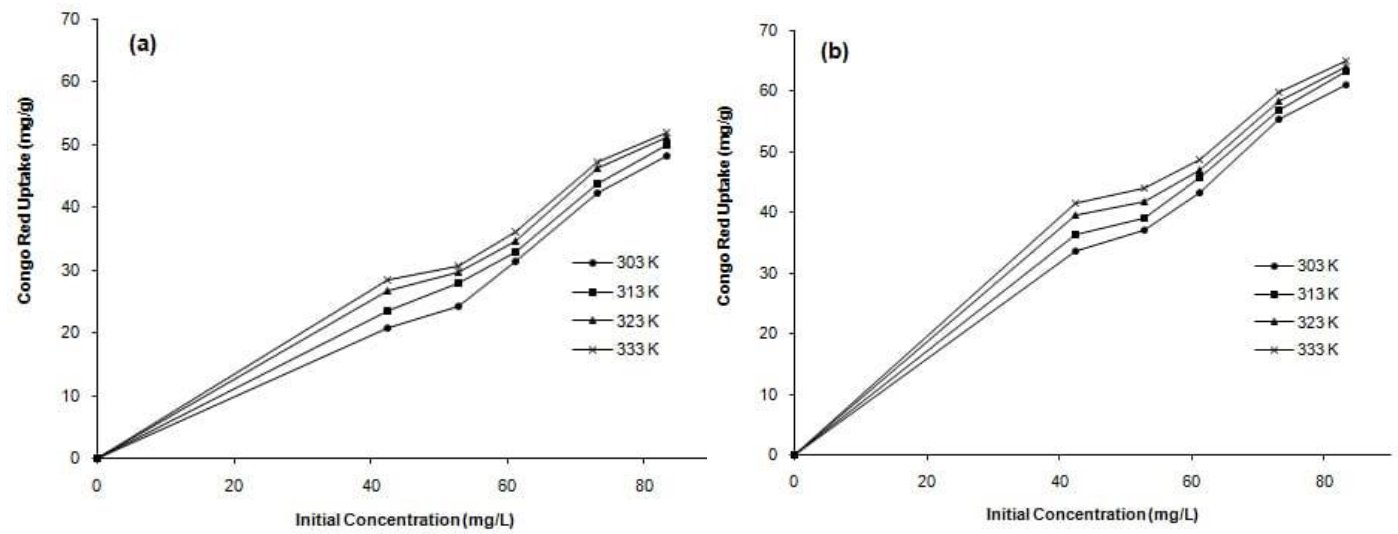

Figure 10. Effect of concentration of congo red and temperature adsorption on $\mathrm{Zn} / \mathrm{Al}$ (a) and citrate- $\mathrm{Zn} / \mathrm{Al}$ (b) LDHs

Figure 10 shows the effect of initial concentration and temperature adsorption of congo red on $\mathrm{Zn} / \mathrm{Al}$ and citrate- $\mathrm{Zn} / \mathrm{Al}$ adsorbents. The amount of congo red adsorbed increased by increasing temperature adsorption. The adsorption profile shows that physical adsorption has occurred in this research. The data of isotherm adsorption was obtain using Langmuir and Freundlich isotherms equation as follows ${ }^{44}$ :

Langmuir equation:

$\frac{\mathrm{C}}{\mathrm{m}}=\frac{1}{\mathrm{bK}}+\frac{\mathrm{C}}{\mathrm{b}}$ where $\mathrm{C}$ is a saturated concentration of adsorbate; $\mathrm{m}$ is the amount of adsorbate; $\mathrm{b}$ is the maximum adsorption capacity $\left(\mathrm{mg} \mathrm{g}^{-1}\right)$, and $\mathrm{K}_{\mathrm{ML}}$ is the Langmuir constant $\left(\mathrm{L} \mathrm{mg}^{-1}\right)$.

Freundlich equation:

$\log \mathrm{q}_{\mathrm{e}}=\log \mathrm{K}_{\mathrm{F}}+1 / \mathrm{n} \log \mathrm{C}_{\mathrm{e}}$

Where $\mathrm{q}_{\mathrm{e}}$ is adsorption capacity at equilibrium (mg $\left.\mathrm{g}^{-1}\right) ; \mathrm{C}_{\mathrm{e}}$ is a concentration of adsorbate at equilibrium $\left(\mathrm{mg} \mathrm{L}^{-1}\right)$, and $\mathrm{K}_{\mathrm{F}}$ is Freundlich constant. The data of isotherm adsorption of congo red on LDHs are shown in Table 3.

Table 3. Isotherm adsorption of congo red.

\begin{tabular}{|c|c|c|c|c|c|c|}
\hline & \multirow{2}{*}{ Isotherm } & \multirow{2}{*}{ Isotherm Parameter } & \multicolumn{4}{|c|}{ Temperature (K) } \\
\hline & & & 303 & 313 & 323 & 333 \\
\hline \multirow{2}{*}{$\mathrm{Zn} / \mathrm{Al}$} & Langmuir & $\begin{array}{c}\mathrm{q}_{\max }\left(\mathrm{mg} \mathrm{g}^{-1}\right) \\
\mathrm{k}_{\mathrm{ML}}\left(\mathrm{L} \mathrm{mg}^{-1}\right) \\
\mathrm{R}^{2}\end{array}$ & $\begin{array}{l}47.619 \\
0.011 \\
0.580\end{array}$ & $\begin{array}{c}111.112 \\
0.007 \\
0.433\end{array}$ & $\begin{array}{c}166.666 \\
0.001 \\
0.429\end{array}$ & $\begin{array}{c}112.045 \\
0.003 \\
0.449\end{array}$ \\
\hline & Freundlich & $\begin{array}{c}\mathrm{k}_{\mathrm{F}}\left(\mathrm{mg} \mathrm{g}^{-1}\right)(\mathrm{L} \mathrm{mg})^{1 / \mathrm{n}} \\
\mathrm{n} \\
\mathrm{R}^{2}\end{array}$ & $\begin{array}{l}0.091 \\
0.608 \\
0.890\end{array}$ & $\begin{array}{l}2.716 \\
0.774 \\
0.922\end{array}$ & $\begin{array}{l}1.315 \\
1.040 \\
0.834\end{array}$ & $\begin{array}{l}2.051 \\
1.175 \\
0.814\end{array}$ \\
\hline \multirow[b]{2}{*}{$\begin{array}{c}\text { Citrate- } \\
\text { Zn/Al }\end{array}$} & Langmuir & $\begin{array}{c}\mathrm{q}_{\max }\left(\mathrm{mg} \mathrm{g}^{-1}\right) \\
\mathrm{K}_{\mathrm{ML}}\left(\mathrm{L} \mathrm{mg} \mathrm{mg}^{-1}\right) \\
\mathrm{R}^{2}\end{array}$ & $\begin{array}{c}249.990 \\
0.009 \\
0.171\end{array}$ & $\begin{array}{c}166.667 \\
0.018 \\
0.426\end{array}$ & $\begin{array}{c}111.111 \\
0.082 \\
0.707\end{array}$ & $\begin{array}{c}90.909 \\
0.070 \\
0.832\end{array}$ \\
\hline & Freundlich & $\begin{array}{c}\mathrm{k}_{\mathrm{F}}\left(\mathrm{mg} \mathrm{g}^{-1}\right)(\mathrm{L} \mathrm{mg})^{1 / \mathrm{n}} \\
\mathrm{n} \\
\mathrm{R}^{2}\end{array}$ & $\begin{array}{l}3.811 \\
1.302 \\
0.818\end{array}$ & $\begin{array}{l}6.561 \\
1.592 \\
0.803\end{array}$ & $\begin{array}{c}12.882 \\
2.283 \\
0.749\end{array}$ & $\begin{array}{c}17.458 \\
2.778 \\
0.769\end{array}$ \\
\hline
\end{tabular}

Table 3 showed that adsorption capacity for citrate$\mathrm{Zn} / \mathrm{Al}$ is higher than pristine $\mathrm{Zn} / \mathrm{Al} \mathrm{LDH}$. The adsorption capacity is up to $249.99 \mathrm{mg} \mathrm{g}^{-1}$ for citrate$\mathrm{Zn} / \mathrm{Al} \mathrm{LDH}$ and $166.67 \mathrm{mg} \mathrm{g}^{-1}$ for $\mathrm{Zn} / \mathrm{Al} \mathrm{LDH}$ without intercalation. The adsorption capacities are related to the increased surface area properties after intercalation. The decreasing of adsorption capacity of intercalated material by increasing temperature is probably due to decreasing pore diameter of intercalated material, as shown in Table 1. The compared materials as adsorbent of congo red were shown in Table 4. 
Table 4. Compared materials as an adsorbent for Congo red dye.

\begin{tabular}{|c|c|c|}
\hline Adsorbent & Adsorption Capacity $(\mathrm{mg} / \mathrm{g})$ & Ref \\
\hline $\mathrm{Ni} / \mathrm{Co} \mathrm{LDH}$ & 909.2 & 45 \\
\hline $\mathrm{Mg} / \mathrm{Fe}-\mathrm{CO}_{3}$ & 104.6 & 46 \\
\hline $\mathrm{Fe}_{3} \mathrm{O}_{4}-\mathrm{MgAl} \mathrm{LDH}$ & 813 & 48 \\
\hline $\mathrm{CNT}-\mathrm{MgAl}-\mathrm{O}$ LDH & 1250 & 49 \\
\hline sodium dodecyl sulfate SDS-LDH & 714 & 50 \\
\hline Borates-Mg/Al LDH & 138.6 & 51 \\
\hline $\mathrm{Ni} / \mathrm{Al}-\mathrm{S}_{1} \mathrm{LDH}$ & 120.5 & 52 \\
\hline $\mathrm{MgO}-\mathrm{GO}$ microspheres & 227.7 & 53 \\
\hline $\mathrm{NiFe}$ LDH & 80.2 & 53 \\
\hline $\mathrm{Mg} / \mathrm{Fe}-\mathrm{NO}_{3} \mathrm{LDH}$ & 58.54 & This work \\
\hline $\mathrm{Zn} / \mathrm{Al}$ LDH & 112.04 & This work \\
\hline $\mathrm{Zn} / \mathrm{Al}-$ citrate & 249.9 & 57 \\
\hline
\end{tabular}

The thermodynamic properties of Congo red adsorption on $\mathrm{Zn} / \mathrm{Al}$ and intercalated $\mathrm{Zn} / \mathrm{Al} \mathrm{LDHs}$ is shown in Table 5 and was calculated according to the equation as follows ${ }^{54}$ :

$\ln \mathrm{KML}=\frac{\Delta \mathrm{S}}{\mathrm{R}}-\frac{\Delta \mathrm{H}}{\mathrm{RT}}$
$\Delta \mathrm{G}^{\mathrm{o}}=-\mathrm{RT} \ln \mathrm{K}_{\mathrm{ML}}$

Where $\mathrm{T}$ is the temperature $(\mathrm{K})$; $\mathrm{R}$ is the gas constant $\left(8.314 \mathrm{~J} \mathrm{~mol}^{-1} \mathrm{~K}^{-1}\right)$, and $\mathrm{K}_{\mathrm{ML}}$ is the modified Langmuir constant.

Table 5. Thermodynamic parameter of Congo red adsorption on LDHs.

\begin{tabular}{|c|c|c|c|c|c|c|}
\hline & \multicolumn{4}{|c|}{$\Delta \mathrm{G}^{\mathrm{o}}\left(\mathrm{kJ} \mathrm{mol}^{-1}\right)$} & \multirow{2}{*}{$\begin{array}{c}\Delta \mathrm{H}^{\mathrm{o}} \\
\left(\mathrm{kJ} \mathrm{mol}^{-1}\right)\end{array}$} & \multirow{2}{*}{$\begin{array}{c}\Delta \mathrm{S}^{\mathrm{o}} \\
\left(\mathrm{J} \mathrm{mol}^{-1} \mathrm{~K}^{-1}\right)\end{array}$} \\
\hline & $303 \mathrm{~K}$ & $313 \mathrm{~K}$ & $323 \mathrm{~K}$ & $333 \mathrm{~K}$ & & \\
\hline $\mathrm{Zn} / \mathrm{Al}$ & -0.213 & -0.355 & -0.497 & -0.638 & 4.085 & 0.014 \\
\hline Citrate-Zn/Al & -1.487 & -1.673 & -1.859 & -2.045 & 4.148 & 0.019 \\
\hline
\end{tabular}

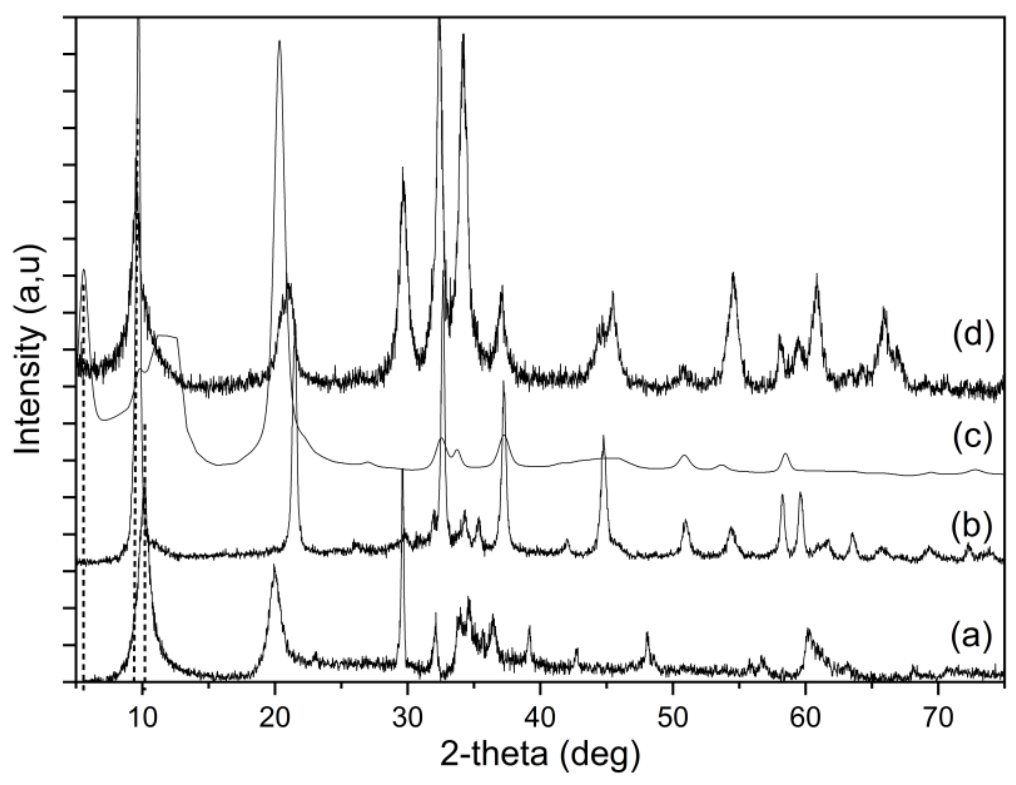

Figure 11. XRD pattern of (a) Zn/Al, (b) Zn/Al after adsorption, (c) Zn/Al-Citrate and (d) Zn/Al-Citrate after adsorption Congo red 
The data in Table 5 showed the value of Gibbs energy, enthalpy, and entropy of Congo red adsorption on LDHs. All adsorption of methyl orange on LDHs was spontaneously occurred due to the negative value of Gibbs energy. Adsorption of Congo red on LDHs was classified as physical adsorption with energy in the range $4.085-4.148 \mathrm{~kJ}$ $\mathrm{mol}^{-1}$ and also there was increasing randomness of adsorption system on both LDHs as adsorbent. The adsorption of Congo red into $\mathrm{Zn} / \mathrm{Al}-\mathrm{Cit} \mathrm{LDH}$ was more efficient than $\mathrm{Zn} / \mathrm{Al} \mathrm{LDH}$. The study of a LDH structure after the adsorption process was conducted using XRD analysis. The pattern of XRD before and after adsorption of Congo red was shown in Figure 11 .

Figure 11.b. shows the LDH pattern after adsorption of Congo red was shifted to lower 2 theta from 10.29 with interlayer distance $8.59 \AA$ to 9.725 with interlayer distance $8.54 \AA$. The interlayer was decreased after adsorption, but the structure of LDH has no change. However, intercalated LDH shows the adsorption capacity higher than pristine LDH. This phenom related that the decrease interlayer after adsorption Congo red and 2 theta shifted to a higher degree. Figure 11. c and d show the shifted with decrease the interlayer distance from $11.68 \AA$ to 8.65 $\AA$ indicated that the Congo red was coated and pilled up the active site so that the XRD confirm that the interlayer decreased slightly. The effectivity of adsorbent was determined by reusability. Desorption study was conducted before the regenerator process, desorption was conducted using several reagents to determine the suitable solvent, and the results were shown in Figure 12.

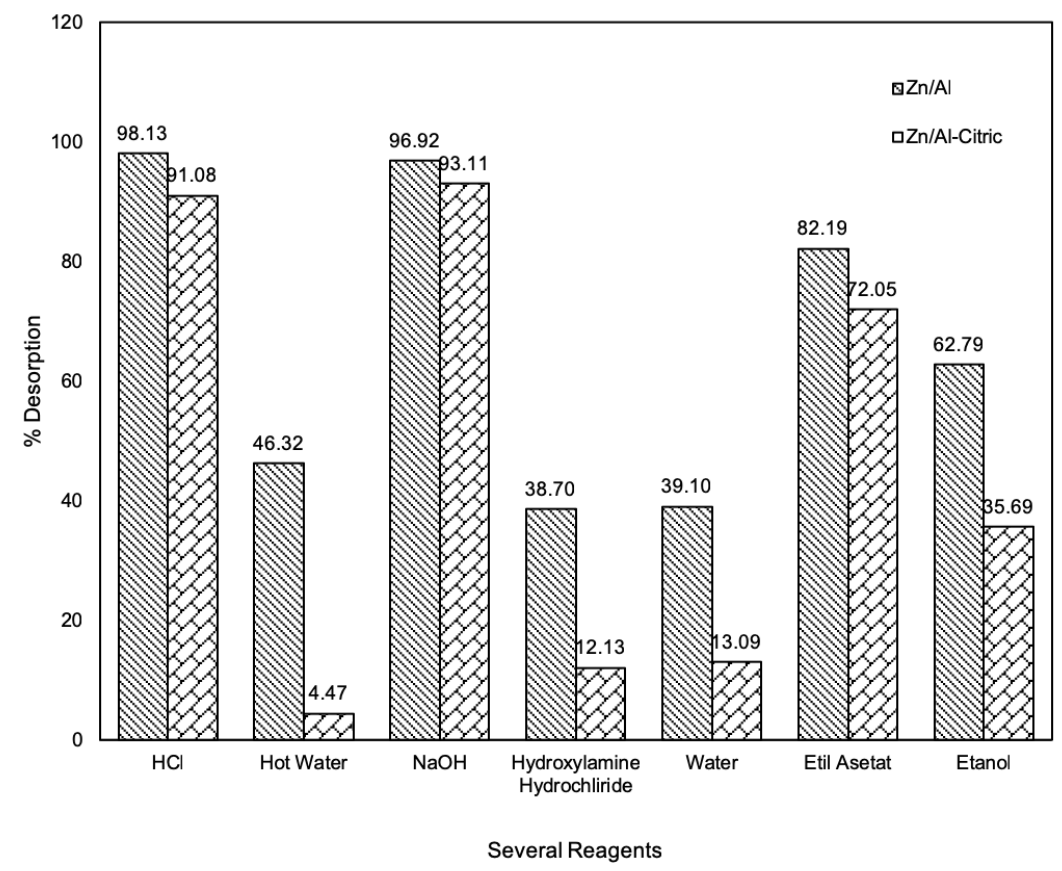

Figure 12. Desorption $\mathrm{Zn} / \mathrm{Al} \mathrm{LDH}$ and $\mathrm{Zn} / \mathrm{Al}-\mathrm{Citrate} \mathrm{LDH}$

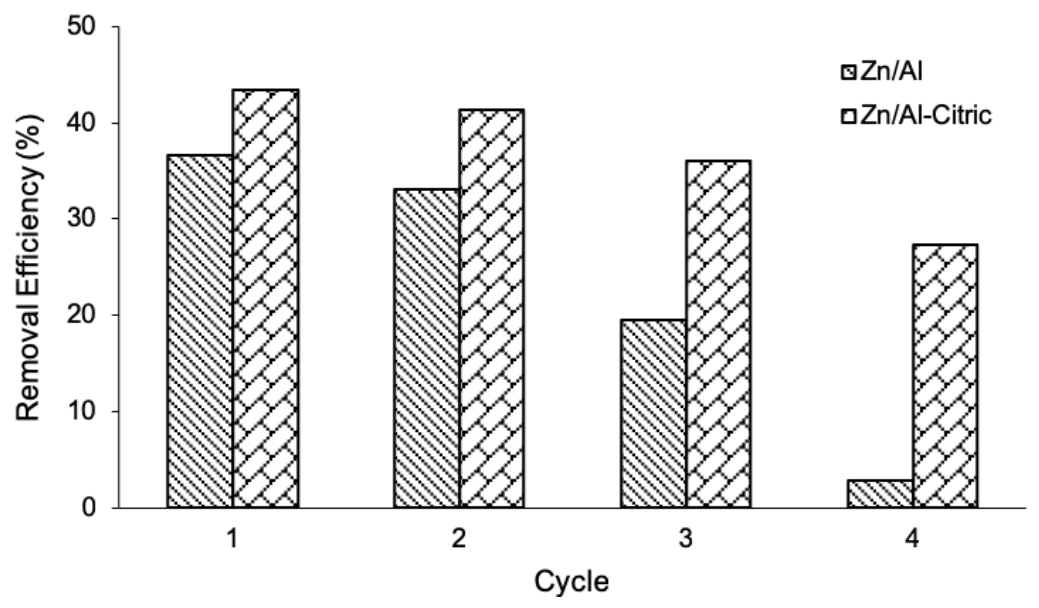

Figure 13. Reusability Zn/Al LDH and Zn/Al-Citrate LDH 
Figure 12 shows the desorption of $\mathrm{Zn} / \mathrm{Al}$ and $\mathrm{Zn} / \mathrm{Al}$ Citrate LDHs were conducted using $\mathrm{HCl}$, hot water, $\mathrm{NaOH}$, hydroxylamine hydrochloride, water, ethyl acetate, and ethanol. Before desorption, both adsorbents were adsorbed the $150 \mathrm{mg} / \mathrm{L}$ of Congo red and adsorbed capacity was $96 \mathrm{mg} / \mathrm{g}$ and $\quad 132$ $\mathrm{mg} / \mathrm{g}$ at room temperature. The adsorbed materials were shaken with each reagent. The result obtained that the $\mathrm{LDH}$ pristine using $\mathrm{HCl}$ uptake $98.13 \%$ and $\mathrm{Zn} / \mathrm{Al}$ intercalated citrate using $\mathrm{NaOH}$ with $93.11 \%$ desorption. Subsequently, $\mathrm{Zn} / \mathrm{Al}$ and $\mathrm{Zn} / \mathrm{Al}$-citrate after desorption used to Congo red adsorption. The removal efficiency of these materials showed in Figure 13.

The removal efficiency of both materials slightly decreased. The $\mathrm{Zn} / \mathrm{Al} \mathrm{LDH}$ was decreased dramatically after a four-cycle process. According to Palapa et al. (2020), the LDH can be exfoliated in acid solution, and $\mathrm{LDH}$ has reduced reusability activity. Nevertheless, $\mathrm{Zn} / \mathrm{Al}$-citrate has more effectivity to reuse as adsorbent ${ }^{40}$. The removal efficiency of $\mathrm{Zn} / \mathrm{Al}$-citrate is quietly decreased until the fourth cycle. The $\mathrm{Zn} / \mathrm{Al}$ after intercalating citrate anion has more efficient as an adsorbent to remove Congo red in water solution.

\section{Conclusion}

Citrate-Zn/Al LDH and pristine LDHs were successfully synthesized and used as adsorbent of Congo red from aqueous solution. The adsorption of Congo red on LDHs follows the pseudo-second-order kinetic model. The adsorption capacity is up to 249.99 $\mathrm{mg} \mathrm{g}^{-1}$ for citric acid-Zn/Al LDH and $166.67 \mathrm{mg} \mathrm{g}^{-1}$ for pristine $\mathrm{LDH}$. The adsorption process was categorized as physical adsorption with energy adsorption 4.085-4.148 $\mathrm{kJ} \mathrm{mol}^{-1}$. The reusability study shows the $\mathrm{Zn} / \mathrm{Al}$ after intercalated citrate anion is efficient and effective use as an adsorbent.

\section{Acknowledgement}

The authors express their gratitude to Ministry of Research Technology and Higher Education (Kemenristekdikti) Republik Indonesia through "Hibah Penelitian Dasar Unggulan Perguruan Tinggi (PDUPT)" in 2019-2020 fiscal year with contract no. 0060.05/UN9/SB3.LP2M.PT/2019.

\section{References}

1- M. K. Dahri, M. R. R. Kooh, L. B. L. Lim, Water remediation using a low-cost adsorbent walnut shell for removal of malachite green: equilibrium, kinetics, thermodynamics and regeneration studies, Journal of Environmental Chemical Engineering, 2019, 2, 1434-1444.

2- M. R. Samarghandi, M. Zarrabi, M. N. Sepehr, R. Panahi, M. Foroghi, Removal of Acid Red 14 by Pumice Stone as a Low-cost Adsorbent: Kinetic and Equilibrium Study, Iranian Journal of Chemistry and Chemical Engineering, 2012, 31, 19-27.

3- C. Shen, Y. Pan, D. Wu, Y. Liu, C. Ma, F. Li, H. Ma, Y. Zhang, A crosslinking-induced precipitation process for the simultaneous removal of poly(vinyl alcohol) and reactive dye: the importance of covalent bond forming and magnesium coagulation, Chemical Engineering Journal, 2019, 374, 904-913.

4- P. J. Ong, S. W. Tay, L. Hong, Removal of water-soluble dyes by conjugated organic skeletons through drain flow-diffusion filtration, Journal of Environmental Chemical Engineering, 2018, 6, 4612-4622.

5- M. Alizadeh, E. Ghahramani, M. Zarrabi, M. N. Sepehr, Efficient de-colorization of methylene blue by the electro-coagulation method: Comparison of iron and aluminum electrode, Iranian Journal of Chemistry and Chemical Engineering, 2015, 34, 39-47.

6- X. L. Cao, Y. N. Yan, F. Y. Zhou, S. P. Sun, Tailoring nanofiltration membranes for effective removing dye intermediates in complex dyewastewater, Journal of Membrane Science, 2020, 595, 117476.

7- M. R. Samarghandi, M. Zarrabi, A. Amrane, M. M. Soori, M. N. Sepehr, Removal of acid black dye by pumice stone as a low-cost adsorbent: kinetic, thermodynamic and equilibrium studies, Environmental Engineering and Management Journal, 2013, 12, 2137-2147.

8- Y. Yang, L. Yan, J. Li, J. Li, T. Yan, M. Sun, Z. Pei, Synergistic adsorption and photocatalytic reduction of $\mathrm{Cr}(\mathrm{VI})$ using $\mathrm{Zn}$-Al-layered double hydroxide and $\mathrm{TiO}_{2}$ composite, Applied Surface Science, 2019, 492, 487-496.

9- N. Parshi, D. Pan, V. Dhavle, B. Jana, S. Maity, J. Ganguly, fabrication of lightweight and reusable salicylaldehyde functionalized chitosan as an adsorbent for dye removal and its mechanism, International Journal of Biological Macromolecules, 2019, 141, 626-635.

10-Y. Song, J. Y. Seo, H. Kim, K. Y. Beak, Structural control of cellulose nanofibrous composite membrane with metal-organic framework (ZIF-8) for highly selective removal of cationic dye, Carbohydrate Polymers, 2019, 222, 115018.

11-T. Taher, D. Rohendi, R. Mohadi, A. Lesbani, Thermal and acid activation (TAA) of bentonite as an adsorbent for removal methylene blue: a kinetics and thermodynamic study, Chiang Mai Journal of Science, 2018, 45, 1770-1781.

12-T. A. Aragaw, F. T. Angerasa, Adsorption of basic yellow dye dataset using Ethiopian kaolin as an adsorbent, Data in Brief, 2019, 26, 104504.

13-H. Quaddari, A. Karim, B. Achiou, S. Saja, A. Aaddane, J. Bennazha, I. E. A. E. Hassani, M. Ouammou, A. Albizane, Now low-cost ultrafiltration membrane made from purified 
natural clays for direct red 80 dye removal, Journal of Environmental Chemical Engineering, 2019, 7, 103268.

14-Q. Huang, M. Liu, J. Chen, Q. Wan, J. Tian, L. Huang, R. Jiang, Y. Wen, X. Zhang, Y Wei, Facile preparation of MoS2 based polymer composites via mussel inspired chemistry and their high efficiency for removal of organic dyes, 2017, 419, 35-44.

15-G. V. Brião, S. L. Jahn, E. L. Foletto, G. L. Dotto, Highly efficient and reusable mesoporous zeolite synthetized from a biopolymer for cationic dyes adsorption, Colloids and Surfaces A: Physicochemical and Engineering Aspects, 2018, 556, 43-50.

16-N. R. Palapa, T. Taher, R. Mohadi, A. Lesbani, Removal of anionic direct dye using $\mathrm{Zn} / \mathrm{Al}$, $\mathrm{Zn} / \mathrm{Fe}$, and $\mathrm{Zn} / \mathrm{Cr}$ layered double hydroxides toward the interlayer distance, Science and Technology Indonesia, 2019, 4, 70-76.

17-L. M. Ahmed, M. S. Gasser, Adsorption study of anionic reactive dye from aqueous solution to $\mathrm{Mg}-\mathrm{Fe}-\mathrm{CO}_{3}$ layered double hydroxide (LDH), Applied Surface Science, 2012, 259,650-656.

18-N. R. Palapa, R. Mohadi, A. Lesbani, Adsorption of direct yellow dye from aqueous solution by $\mathrm{Ni} / \mathrm{Al}$ and $\mathrm{Zn} / \mathrm{Al}$ layered double hydroxides, AIP Conference Proceeding, 2018, 2026, 020018.

19-N. R. Palapa, T. Taher, R. Mohadi, M. Said, A. Lesbani, Synthesis of Ni/Al layered double hydroxides (LDHs) for adsorption of malachite green and direct yellow dyes from solution: kinetic and thermodynamic, AIP Conference Proceeding, 2018, 2026, 020033.

20-G. Huang, L. Jiang, D. Wang, J. Chen, Z. Li, S. Ma, Intercalation of thiacalix[4]arene anion via calcined/restored reaction into $\mathrm{LDH}$ and efficient heavy metal capture, Journal of Molecular Liquids, 2016, 220, 346-353.

21-T. Taher, Y. Irianty, R. Mohadi, M. Said, R. Andreas, A. Lesbani, Adsorption of cadmium(II) using $\mathrm{Ca} / \mathrm{Al}$ layered double hydroxides intercalated with Keggin ion, Indonesian Journal of Chemistry, 2019, 19, 873-881.

22-T. Taher, M. M. Christina, M. Said, N. Hidayati, Ferlinahayati, A. Lesbani, Removal of iron(II) using intercalated $\mathrm{Ca} / \mathrm{Al}$ layered double hydroxides with $\left[\alpha-\mathrm{SiW}_{12} \mathrm{O}_{40}\right]^{4-}$, Bulletin of Chemical Reaction Engineering and Catalysis, 2019, 14, 260-267.

23-M. Szabados, G. Varga, Z. Kónya, Á. Kukovecz, S. Carlson, P. Sipos, I. Pálinkó, Ultrasonicallyenhanced preparation, characterization of $\mathrm{CaFe}$ layered double hydroxides with various interlayer halide, azide and oxo anions $\left(\mathrm{CO}_{3}{ }^{2-}, \mathrm{NO}_{3}{ }^{-}, \mathrm{ClO}_{4}^{-}\right)$, Ultrasonic Sonochemistry, 2018, 40, 853-860.

24-M. Shafigh, M. Hamidpour, G. Furrer, Zinc release from $\mathrm{Zn}-\mathrm{Mg}$-Fe(III)-LDH intercalated with nitrate, phosphate and carbonate: the effects of low molecular weight organic acids, Applied Clay Science, 2019, 170, 135-142.

25-H. Chen, J. Lin, N. Zhang, L. Chen, S. Zhong, Y. Wang, W. Zhang, Q. Ling, Preparation of MgAl-EDTA-LDH based electrospun nanofiber membrane and its adsorption properties of copper(II) from wastewater, Journal of Hazardous Materials, 2018, 345, 1-9.

26-R. Lafi, K. Charradi, M. A. Djebbi, A. B. H. Amara, A. Hafiane, Adsorption study of Congo red from aqueous solution to $\mathrm{Mg}$-Al-layered double hydroxide, Advanced Powder Technology, 2016, 27, 232-237.

27-F. Mohamed, M. R. Abukhadra, M. Shaban, removal of safranin dye from water using polypyrrole nanofiber/Zn-Fe layered double hydroxide nanocomposite (PpyNF/Zn-Fe LDH) of enhanced adsorption and photocatalytic properties, Science of the Total Environment, 2018, 640-641, 352-363.

28-M. A. Ahmed, A. A. Brick, A. A. Mohamed, An efficient adsorption of indigo carmine dye from aqueous solution on mesoporous $\mathrm{Mg} / \mathrm{Fe}$ layered double hydroxide nanoparticles prepared by controlled sol-gel route, Chemosphere, 2017, 174, 280-288.

29-G. George, M. P. Saravanakumar, Facile synthesis of carbon-coated layered double hydroxide and its comparative characterization with Zn-Al LDH: application on crystal violet and malachite green dye adsorption-isotherm, kinetics and Box-Behnken design, Environment Science and Pollution Research, 2018, 25, 30236-30254.

30-B. Bi, B. Xu, X. Liu, Heteropoly blueintercalated layered double hydroxides for cationic dye removal from aqueous media, Applied Clay Science, 2011, 54, 242-247.

31-N. R. Palapa, T. Taher, R. Mohadi, A. Lesbani, Kinetic aspect of direct violet adsorption on $\mathrm{M}^{2+} / \mathrm{M}^{3+}\left(\mathrm{M}^{2+}=\mathrm{Zn}, \mathrm{M}^{3+}=\mathrm{Al}, \mathrm{Fe}, \mathrm{Cr}\right)$ layered double hydroxide, AIP Conference Proceeding, 2019, 2194, 020079.

32-B. R. Rahayu, T. Taher, P. L. Hariani, A. Lesbani, Congo red and direct yellow dye removal from aqueous solution by $\mathrm{Zn} / \mathrm{Cr}$ layered double hydroxides, AIP Conference Proceeding, 2018, 2026, 020023.

33-M. Oktriyanti, N. R. Palapa, R. Mohadi, A. Lesbani, Modification of $\mathrm{Zn}$-Cr layered double hydroxide with Keggin ion $\left[\mathrm{SiW}_{12} \mathrm{O}_{40}\right]$ as $\mathrm{Cr}(\mathrm{VI})$ adsorbent, Indonesian Journal of Environmental Management and Sustainability, 2019, 3, 93-99.

34-H. N. Tran, C. C. Lin, S. H. Woo, H. P. Chao, Efficient removal of copper and lead by $\mathrm{Mg} / \mathrm{Al}$ layered double hydroxides intercalated with organic acid anions: adsorption kinetics, 
isotherms, and thermodynamics, Applied Clay Science, 2018, 154, 17-27.

35-M. L-Sánchez, G. N-Maléndez, G. Luna, V. S. Pérez, J. A. Rivera, G. Fetter, ZnAl layered double hydroxides impregnated with eucalyptus oil as efficient hybrid materials against multiresistant bacteria, Applied Clay Science, 2018, 153, 61-69.

36-H. N. Umh, Y. Kim, Sensitivity of nanoparticles' stability at the point of zero charge (PZC), Journal of Industrial and Engineering Chemistry, 2014, 20, 3175-3178.

37-Y. Wang, Y. Zhang, B. Zhou, C. Li, F. Gao, X. Wang, D. Liang, Y. Wei, In-situ observation of the growth behavior of $\mathrm{ZnAl}$ layered double hydroxide film using EQCM, Materials and Design, 2019, 180, 107952.

38-M. Dinari, A. Haghighi, P. Asadi, Facile synthesis of ZnAl-EDTA layered double hydroxide/poly(vinyl alcohol) nanocomposites as an efficient adsorbent of Cd(II) ions from the aqueous solution, Applied Clay Science, 2019, 170, 21-28.

39-S. Yudarkal, C. Garlisi, L. Özcan, M. Bellardita, G. Palmisano, Photocatalyst characterization techniques: adsorption isotherms and BET, SEM, FTIR, UV-Vis, photoluminescence, and electrochemical characterizations, Heterogeneous Photocatalysis, Elsevier, 2019, 87-152.

40-N. R. Palapa, R. Mohadi, A. Rachmat, A. Lesbani, Adsorption Study of Malachite Green Removal from Aqueous Solution Using $\mathrm{Cu} / \mathrm{M}^{3+}\left(\mathrm{M}^{3+}=\mathrm{Al}, \mathrm{Cr}\right)$ Layered Double Hydroxide, Mediterranean Journal of Chemistry, 2020, 10, 33-45.

41-O. Rahmanian, S. Amini, M. Dinari, Preparation of zinc/iron layered double hydroxide intercalated by citrate anion for capturing Lead (II) from aqueous solution, Journal of Molecular Liquids, 2018, 256, 9-15.

42-T. Taher, R. Mohadi, A. Lesbani, Effect of $\mathrm{Ti}^{4+} /$ clay ratio on the properties of titanium pillared bentonite and its application for $\mathrm{Cr}(\mathrm{VI})$ removal, Rasayan Journal of Chemistry, 2018, $11,1244-1254$

43-M. N. Sepehr, S. Nasseri, M. Zarrabi. Removal of $\mathrm{Cr}$ (III) from tanning effluent by Aspergillus niger in airlift bioreactor, Separation and Purification Technology, 2012, 96, 256-262.

44-T. Taher, R. Mohadi, D. Rohendi, A. Lesbani, Congo red removal from aqueous solution by acid-activated bentonite from Sorolangun: kinetic, equilibrium, and thermodynamic studies, Arab Journal of Basic and Applied Sciences, 2019, 26, 125-136.
45-H. Hu, J. Liu, Z. Xu, L. Zhang, B. Cheng, W. Ho, Hierarchical porous Ni/Co-LDH hollow dodecahedron with excellent adsorption property for Congo red and Cr (VI) ions, Applied Surface Science, 2019, 478, 981-990.

46-I. M. Ahmed, M. S. Gasser, Adsorption study of anionic reactive dye from aqueous solution to $\mathrm{Mg}-\mathrm{Fe}-\mathrm{CO}_{3}$ layered double hydroxide (LDH), Applied surface science, 2012, 259, 650-656.

47-L. Lu, J. Li, D. H. Ng, P. Yang, P. Song, M. Zuo, Synthesis of novel hierarchically porous $\mathrm{Fe}_{3} \mathrm{O}_{4} @ \mathrm{MgAl}-\mathrm{LDH}$ magnetic microspheres and its superb adsorption properties of dye from water, Journal of Industrial and Engineering Chemistry, 2017, 46, 315-323.

48-S. Yang, L. Wang, X. Zhang, W. Yang, G. Song, Enhanced adsorption of Congo red dye by functionalized carbon nanotube/mixed metal oxides nanocomposites derived from layered double hydroxide precursor, Chemical Engineering Journal, 2015, 275, 315-321.

49-L. Deng, H. Zeng, Z. Shi, W. Zhang, J. Luo, Sodium dodecyl sulfate intercalated and acrylamide anchored layered double hydroxides: A multifunctional adsorbent for highly efficient removal of Congo red, Journal of colloid and interface science, 2018, 521, 172-182.

50-Y. H. Jia, Z. H. Liu, Preparation of borate anions intercalated $\mathrm{MgAl}$-LDHs microsphere and its calcinated product with superior adsorption performance for Congo red, Colloids and Surfaces A: Physicochemical and Engineering Aspects, 2019, 575, 373-381.

51-D. Bharali, R. C. Deka, Adsorptive removal of congo red from aqueous solution by sonochemically synthesized $\mathrm{NiAl}$ layered double hydroxide, Journal of environmental chemical engineering, 2017, 5, 2056-2067.

52-J. Xu, D. Xu, B. Zhu, B. Cheng, C. Jiang, Adsorptive removal of an anionic dye Congo red by flower-like hierarchical magnesium oxide (MgO)-graphene oxide composite microspheres, Applied Surface Science, 2018, 435, 1136-1142.

53-N. Hidayati, D. R. Apriliani, T. Taher,

R. Mohadi, A. Lesbani, Adsorption of congo red using $\mathrm{Mg} / \mathrm{Fe}$ and $\mathrm{Ni} / \mathrm{Fe}$ layered double hydroxides, In Journal of Physics: Conference Series IOP Publishing, 2019, 1282, 012075.

54-S. Agarwal, I. Tyagi, V. K. Gupta, S. Mashhadi, M. Ghasemi, Kinetic and thermodynamics of malachite green dye removal from aqueous phase using iron nanoparticles loaded on ash, Journal of Molecular Liquids, 2016, 223, 1340-1347. 